Article

\title{
An Analysis of Water Awareness Campaign Messaging in the Case of Jordan: Water Conservation for State Security
}

\author{
Skylar Benedict ${ }^{1}$ and Hussam Hussein ${ }^{2,3, * \text { CD }}$ \\ 1 Harriet L. Wilkes Honors College, Florida Atlantic University, Jupiter, FL 33458, USA; \\ sb1435@georgetown.edu \\ 2 Department of International Agricultural Policy and Environmental Governance, University of Kassel, \\ Steinstraße 19, 37213 Witzenhausen, Germany \\ 3 Water Security Research Centre and Tyndall Centre for Climate Change Research, School of International \\ Development, University of East Anglia, Norwich NR4 7TJ, UK \\ * Correspondence: hh.hussam.hussein@gmail.com; Tel.: +49-5542-98-1264
}

Received: 16 April 2019; Accepted: 25 May 2019; Published: 1 June 2019

\begin{abstract}
This article examines water awareness campaign messaging of the Water Efficiency and Public Information for Action (WEPIA) campaign. Using Jordanian government documents and structured interviews, it argues that the Ministry of Water and Irrigation (MWI) promotes water awareness campaigns to shape water users' habits and perspectives on water. The goal of this strategy is to align popular concerns about water security with government concerns over state security, i.e., to create responsible water citizens. This article suggests that the Jordanian MWI seeks to shape citizens' water behavior through two key strategies. First, it convinces the population to shift its habits using ideas of national responsibility for the nation's water network. Second, it disseminates a topically diverse combination of water awareness materials to the Jordanian population to shape their water habits in a manner that supports state security.
\end{abstract}

Keywords: water security; water conservation; Jordan; hydropolitics; water scarcity

\section{Introduction}

Jordan is said to be among the most water-scarce countries in the world; according to the Ministry of Water and Irrigation (MWI), Jordan is the second most water scarce country worldwide. The reasons behind water scarcity are natural (i.e., climate change and insufficient precipitation), political (i.e., transboundary nature of most of the surface water resources in the country), infrastructural (i.e., high rate of non-revenue water (NRW), illegal connections, and physical leakages and losses), and social (i.e., increasing demand due to a growing population and in-migration of refugees). To solve water scarcity, the MWI has been exploring different solutions, focusing mainly on increasing the water supply, but also on reducing the demand, including water conservation campaigns.

This article examines the water awareness campaigns of the MWI, and it argues that the MWI's water awareness campaigns use two specific security discourses to legitimate both state ownership over water and interventions in people's daily water practices. The first type of discourse guiding these campaigns, which we label the "state insecurity" discourse, asserts that implementing rationing policies on Jordan's domestic water supply leads to protests and political instability, responses that create a security threat to the state itself. The second type of discourse, which we label the "citizen insecurity" discourse, suggests that people's daily water practices, if wasteful or ineffective, can exacerbate water scarcity, and so create a security risk to their own water access. The connection between these two security discourses is the behavior and daily practices of water users in Jordan. The first discourse 
focuses on the outcomes of the state's previous attempts to implement a supply-side approach to water misuse and how that has led to developing a demand-side approach, and the second addresses the misuse itself-but in both cases, state insecurity around water is rooted in people's management of water resources.

Therefore, water awareness campaigns have targeted people at all levels of Jordanian society in order to convince them to follow the Jordanian government's advice on the use and conservation of water. Through water awareness programs, the state aims to convince the public to accept the second discourse to lessen the security threat laid out in the first discourse. Water awareness programs aim to accomplish this by aligning popular concerns about water security with government concerns over state security; i.e., to create responsible water citizens. The MWI believes that national stability and security, as well as a sustainable future, depend on water usage being firmly under central government control, and views areas of local water hardship as potential sites of state insecurity. The aim of this paper, therefore, is to shed light on how a government faced with a severe national water crisis "secures" a more water-conscious citizen using the two security discourses introduced above.

This article is divided into five sections. The first introductory section presents a background on the responses to the government's previous supply reduction policies and assessments of water security threats. The second section describes the conceptual basis underpinning the study. The third section presents its methodology. The fourth follows by examining how the Jordanian government is shaping individuals' water conservation behaviors in the context of education, religious observance, and legal and financial regimes of responsibility. The fifth then provides some concluding remarks.

General Background: Previous Responses to Supply Reduction Policies and Their Impact on Government Water Security Assessments

This section analyses public perspectives on water conservation and previous responses to policies of supply reduction as two key factors in the government assessment of Jordan's water conservation awareness programs within the MWI's water strategy. In fact, water conservation policies, such as raising awareness to change the behavior of citizens and convince them to use less water in their daily water practices, would decrease the overall water demand and would be a cheaper solution than increasing the supply through the construction of costly desalination plants or through other infrastructural projects. It is obvious that conservation campaigns are part of the overall solution, which would need to be adopted together with other solutions. Interviews with MWI officials and civil society workers revealed that public misgivings about water conservation and supply reduction were two of the main reasons why the MWI decided to engage in outreach campaigns [1-3]. In fact, the MWI realized that it is necessary to improve communication and outreach to the broader population in order to better explain why it is important to conserve water, showing also the work that the MWI is and has been doing to ensure water security in the country.

Historically, the Jordanian government might best be categorized as a relatively strong state that has worked to exert very direct control over the management of the country's water resources in local communities [4]. Since the 1950s at least, the central government has worked with the support of international donors and development organizations to centralize control of the nation's water resources and harness them to support progressive and varied influxes of refugees throughout the decades after Jordan's independence in 1946. Prior to the influxes of refugees that would begin with the Palestine War (al-Nakba) of 1948, the population of the Jordan Valley met its needs through rain-fed agriculture, and so were largely dependent on seasonal fluctuations in rainfall and river flows. Because of the limited size of this population and its distribution across Jordan, there was no need to extract or redirect large portions of water across Jordan's landscape. Sharif Elmusa notes that this low population density was the case, in part, because "British interest in creating the state of Jordan itself stemmed from geopolitical rather than developmental priorities connected to state building [as] Transjordan had hardly any agricultural or mineral resources worth coveting" [5]. This geopolitical interest in Jordan's potential only grew as the American diplomatic and military presence gradually replaced the older 
British one, and the founding of the State of Israel in 1948 created successive waves of refugees, many of whom settled in Jordan. It was the first influx of Palestinian refugees resulting from the $1948 \mathrm{Nakba}$ that sufficiently attracted the attention of the international community to begin large scale development of the Jordanian water sector. The 1948 influx of Palestinian refugees into Jordan forged together three key elements that shape Jordan's development of water resources up to the present: the demographic pressures of refugee populations, resulting concerns over the sufficiency of Jordan's water resources, and the role of international development aid in stabilizing Jordan against the potential of these two interrelated factors to threaten the state's security. It is this set of geopolitical interests and international relations and dependencies that must serve as a lens for viewing the influxes of Syrian refugees in the current decade, and the Jordanian government's current combination of supply-side and demand-side water management. Within this broader context, the MWI and its international partners have worked to augment Jordan's water resources through demand management techniques to bring together Jordan's multi-national population over the collective goal of conserving water and to mitigate tensions between refugees and Jordanians over potential water supply shortages. To avoid such unrest, as well as to avoid employing unpopular water supply reduction techniques, the MWI and its international partners sought to change the view that water conservation was not a viable means to alleviate Jordan's water crisis because it forced average Jordanians to accept a reduced domestic water supply. Regularly supplementing one's reduced access to public water with purchased water was to many a form of luxury only financially feasible for a small portion of society; thus, water conservation, when viewed as a reduction in domestic water supply, was viewed as a form of luxury as well $[1,6]$. The MWI has worked both internally and within the public sphere to eliminate this notion, and to rearticulate its role in securing water for its citizens as a role of knowledge sharing and water conservation education.

Relatedly, the idea of luxury is most likely a function of the impacts of water rationing on the Jordanian public since this policy was initiated in the 1960s [6]. As confirmed in an interview and water strategy document at the MWI, one of the Ministry's concerns is that the public has historically not always accepted policies of water supply reduction, and in fact has met changes in water policy with varying forms of disobedience [2,7]. These acts of resistance include people not changing their water consumption habits, illegal water extraction, misusing and damaging water measurement devices, damaging the broader national water infrastructure [7], and more recently, popular demonstrations against national water carriers [8,9]. In this context, the MWI has turned to water awareness discourses of the second type, which focuses on linking people's water habits to the long-term security of their water supply. We argue that the reason for this focus is the state's concern that the misalignment between people's water use practices and MWI policy has resulted in direct, if mostly small-scale, security threats. Therefore, the Jordanian government's true concerns fit within the first type of discourse, i.e., political instability as a threat to the security of state property and technical apparatuses, and thus Jordanian domestic security in a broader sense [10]. However, it uses water awareness programs based on the second type of discourses to shift people's water habits and provide an alternative to the strict water rationing policies, which have previously caused instability. Previous investigations of water conservation behaviors in Jordan [11] illustrate both the broader lack of impact demographic distinctions have on water habits, but also the relatively limited popularity of a variety of different forms of conservation. This article builds on such social studies of Jordanian conservation behavior and its determinants by illustrating the Jordanian government's response to public concerns over supply reduction and the techniques that it has employed to drive large-scale adoption of water conservation behaviors and mitigate the risks that imprudent usage of water resources creates.

Assessing the impact of these two factors motivated a shift towards water conservation awareness programs as a method of demand management. In order to mitigate these risks, the MWI has developed water conservation awareness programs to shift the misconception that water security will necessitate supply-side management. These programs emphasize all the ways that everyday citizens can participate in demand management practices to reduce the burden on the nation's water in an attempt to popularize water saving behaviors. The added demographic pressures on Jordan's water 
resources brought by Syrian refugees since the start of the Syrian War in 2012 have further loaded this topic with meaning and tension [12]. An MWI official corroborated the continued relevance of the link between supply reduction and conservation awareness saying, "there is a philosophy of awareness here in Jordan, we are not asking the people to reduce the amount of water but to use water wisely. [Showing] how to deal with the small amount that [each] receives [ ... ] we teach each how [ ... ] [to] deal with this small amount of water. [To do this] we went to all the sectors in Jordan" [2]. This distinction between changing people's methods of water use and asking them to accept a reduced water quota suggests that the Jordanian government seeks to avoid increased water rationing. Based on the factors discussed above, we argue that the government does so out of concern that the public will react with increased non-compliance and threaten the security of the nation's water infrastructure. Therefore, the government has reached out to all sectors of Jordanian society-domestic, agricultural, and otherwise - to avoid non-compliance and the threats to the water infrastructure that it may bring. The water awareness outreach programs that it uses are therefore multi-faceted and tailored to address water sector actors of all kinds, and seek to utilize knowledge of effective water conservation and management to create greater public compliance of water policy shifts, and to legitimate government authority in water resource usage and management across all sectors.

\section{Conceptual Basis}

This article builds on the literature of water conservation, drawing in particular on the writing of March, Zietlow, and Atallah. March et al. [13] showed the necessity of shaping citizens' perceptions and understanding on water scarcity in order to successfully run behavioral change campaigns, especially in arid and semi-arid regions. March et al. [14] also emphasized the need for deep knowledge on the current water uses of all segments of society in order to design a targeted and effective awareness campaign. Magiera et al. [15] found that there has been an improvement over the years in the Levant region about the awareness the larger population has of water issues, especially thanks to governmental awareness raising campaigns. Atallah et al. [16] have been calling for including religious examples in the awareness raising campaigns on water in the Levant in order to better reach a wider portion of the population. This was then analyzed by Hussein [17] for the case of Jordanian textbooks and water. Finally, Zietlow et al. [18] examined the impact of the "Abu Tawfeer" campaign on the local population's water behavior in Jordan. This article builds on this vast literature, drawing in particular on the concepts of "hydraulic citizenship" and "textual domination".

In speaking of state-citizen engagement, this article retains Nikhil Anand's definition of hydraulic citizenship as a form of belonging articulated through everyday material claims on the nation's water supply and water infrastructure [19]. What this suggests is that the Jordanian government's effort to "create a culture of water conservation for all parts of society" does not discriminate between Jordanians and non-Jordanians, but seeks to instill the same respect for state authority and personal water responsibility in all water users [20]. For all residents of a city, Anand argues, water services structure the substantive ways in which both citizens can see the state and assess the efficacy of its authority, but also the ways in which the state sees citizens [21]. However, in contrast to Anand's case study of hydraulic citizenship in Mumbai, wherein hydraulic citizenship becomes a way for people to articulate claims on the state, in Jordan, the MWI uses a discourse of hydraulic citizenship as a way to make claims on the responsibilities and behaviors of its people, and underpins this discourse with a wide series of legal and financial structures [21].

The literature has found that the primary method states use to invoke this notion of citizen responsibility is by producing and distributing official texts on water management. These texts often frame water use in terms of types of coercive authority, such as financial cost, legal repercussions, and leveraging the security discourse of personal resource shortages and their link to personal water use habits. In seeking to cultivate this understanding between water users and the state, states aim at a form of what Brinkley Messick terms textual domination [22]. This entails the interlocking of a polity, a social order, and a discursive formation to convince and coerce citizens to accept the rules of the state 
in their lives and reform their habits in a way that supports the state's water policies [22] in line with the discourse on state insecurity.

\section{Methodology}

The article adopts a qualitative methodology. Two primary methods of data collection have been used to collect the data that informs this article: semi-structured interviews (see Table 1), and primary source texts produced through Jordan's Water Efficiency and Public Information for Action (WEPIA) program. The second author of the article conducted fieldwork and data collection in 2014, 2015, and 2018 conducting 89 semi-structured interviews on water resources management, while the first author conducted 12 in-depth, semi-structured interviews in 2016 on the topic of water conservation. The first author developed interview questions based on emic coding and content text analysis of Jordanian government documents, in particular, drawing on the national water strategies for 2008-2022, and 2016-2030. Emic coding of these official documents produced a set of themes and discourses on the key causal factors in Jordan's current water scarcity challenges and the daily practices and methods necessary to alleviate water scarcity issues through demand management. The first author then shaped these emic themes into interview questions that asked participants their views on the reasons behind Jordan's water scarcity, gauged the extent to which they employed daily practices in water conservation and management, and provided a framework discussion of their encounters and relationship with the Jordanian state and its various organs through water access and conservation. The first author developed interview follow-up questions within the interview process deductively to address the hypothesis that the Jordanian government has identified people's water behavior as a security threat. It was also key to structure these questions in an open way that did not impose any sort of value judgements on the possible rationales or goals of the Jordanian government's water conservation awareness programs. Instead, any etic interview questions sought to avoid guiding language or bias with interview prompts, such as asking participants to describe their interactions with the government's water awareness program, and also their daily methods of water use. The sample of participants was selected by analyzing who was implementing and involved in the water conservation campaigns, as well as through a snowball approach; the sample identified was: Jordanian academics, governmental officials mainly from the MWI (different levels of responsibilities within the ministry), Non-Governmental Organizations (NGOs), refugees, farmers, rural communities, donors, and international organizations. Moreover, triangulation of methods and of sources has been adopted in order to limit check and improve the validity of the study by analyzing the issue from multiple perspectives. The data collected have been analyzed using a discourse analysis method of data analysis.

Table 1. Number of interviews per group.

\begin{tabular}{ll}
\hline Group & Number of interviews \\
\hline Governmental employees & 24 \\
Donor organization employees & 13 \\
Employees of NGOs & 21 \\
Academics & 12 \\
International organization employees & 6 \\
Farmers & 6 \\
Diplomats & 6 \\
Bedouins & 5 \\
Members of the parliament & 4 \\
Employees of industries & 3 \\
Former ministers & 3 \\
Research institutes employees & 4 \\
Employees of water utilities & 2 \\
Water Users Association employees & 2 \\
Teachers & 2 \\
Journalists & 1 \\
Representatives of political parties & 1 \\
Syrian refugees & 3 \\
\hline
\end{tabular}


Concerning primary source analysis, we, the authors, analyzed Jordanian newspaper articles and academic articles published on the topic, textbooks used in primary and middle school, and 28 reports. Seven were from international organizations and NGOs, while the remaining were produced by the MWI, such as the national water strategy. In addition, material produced by the Department of Media and Water Awareness (DMWA) of the MWI was also collected. Concerning the latter, a few of these documents were geared towards students' water education, but the majority were geared towards the public at large. These included a list of water conservation tips sent out to Jordanians via text message by cooperating cell phone providers, two pamphlets approaching the use of water from an Islamic perspective, and many more dealing with water issues from perspectives that ranged from environment and ecology to sewage and waste water, and general water services, among others. The elements of conservation discourse analyzed within these documents included personal habits of domestic water conservation, statements on the relationship between government responsibilities for effective water provision and citizen responsibilities for conservation through respect of government infrastructure and support of the effective payment of water costs, and invocations of the relationship between water conservation, patriotism, and religious piety.

Through the analysis of these primary source documents and semi-structured interviews, we sought to balance a deductive approach to the data based upon the hypothesis that the Jordanian government has identified people's water behaviors as a water security threat, with inductive adaptability that allowed us to recognize emerging themes and restructure our approach to incorporate them as the research progressed. Developing a combination of emic and etic codes for these documents revealed the relationships between government goals, methods, and outcomes that we put forth in this paper. Triangulation in terms of sources and methods has been deployed in order to test and refine the robustness of the data and hypothesis of this research.

\section{Results and Discussion: Key Factors in Shaping Water Conservation Behavior}

This section, drawing on the concepts of hydraulic citizenship and textual domination, shows how the Jordanian government is shaping individuals' water conservation behaviors in the contexts of legal and financial regimes of responsibilities, religious observation, and education. With hydraulic citizenship, we mean a collection of the state's claims on the responsibilities and behaviors of its people, enforced by a wide series of legal and financial structures. With textual domination, we mean the state's attempt to interlock Jordan's polity and social order, with the related discourses of citizen insecurity and state insecurity to convince and coerce citizens to accept the rules of the state in their lives and reform their habits in a way that supports the state's water policies [22]. The primary method for accomplishing this textual domination is the country's water awareness program, which seeks to address all connected forms of social, domestic, industrial, and agricultural contexts that water use pervades.

\subsection{Hydraulic Citizenship in Jordan}

The concepts of hydraulic citizenship and of textual domination are both central to understanding the Jordanian government's project of shaping public water behaviors to mitigate its current water scarcity crisis. Ministry outreach programs present to the citizens information concerning the water situation in the country, messages about water awareness, tips and suggestions on how can conserve water, and how they can directly help their nation. Doing so centralizes supporting the nation and accepting the legitimacy of the state's water management knowledge and authority. Therefore, to be a productive hydraulic citizen, one must enact the state's advice on water resource management within daily water routines [23]. Connecting water conservation to nationalism links the Jordanian public's concerns with the continued security of their personal water supplies to maintaining the nation's water security. This rhetoric depicts water as an existential necessity for Jordan, suggesting that "water is life. It is the basis of the existence, growth, and development of the living being" [24]. Therefore, the MWI uses the second discourse that we described earlier, "citizen insecurity", to convince citizens that 
their water supply is at risk, and the best way to mitigate this risk is to take the first discourse, "state insecurity," into account in their water behaviors and treatment of the national water infrastructure.

As a result, the best way to think about state-individual engagement in the water sector is through participation in Jordan's hydraulic infrastructure, rather than legal citizenship. This remains an important point of clarification in Jordan because, with the exception of refugee camps, refugees and migrant workers living in urban areas access the Kingdom's water resources through the same set of processes that Jordanian citizens do. As such, they experience the same demographic pressures as Jordanians [25].

\subsection{Textual Domination in Jordan}

The MWI produces its strategy documents, annual reports, and water conservation outreach materials, interweaving the state insecurity discourse with the citizen insecurity discourse to convince water users in Jordan to accept that hydraulic citizenship benefits them but also entails a set of non-negotiable responsibilities to the state. In printing and distributing these documents, the MWI seeks citizens' acceptance of state interventions in people's daily water practices, which emphasize the protection of state institutions and the recognition of state authority in maintaining the security of Jordan's water supply. In seeking to cultivate this understanding between water users and the state, the MWI aims at a form of what Brinkley Messick terms textual domination. This entails the interlocking of a polity, a social order, and a discursive formation to convince and coerce citizens to accept the rules of the state in their lives and reform their habits in a way that supports the state's water policies [22] in line with the discourse on state insecurity. The Jordanian water sector interlocks these three categories through its government-controlled management framework, which seeks to fully encompass and manage all connected forms of social, domestic, industrial, and agricultural contexts that water use pervades. It codifies these relationships within national water laws and seeks to embed the discourses of interwoven state and citizen insecurity within the country's social order by publishing and distributing water awareness materials as a key part of the larger water conservation awareness program. Furthermore, the Jordanian government cultivates deference towards this water management framework through these materials in a manner that places water conservation behavior within the context of pre-existing forms of legal and financial authority. It is by printing and distributing these materials that the state securitizes public water behaviors.

In Jordan, printing and distributing conservation awareness publications constitutes a concrete form of "uttering security" that builds momentum and authority by gradually articulating a discursive shift in water policy, instead of relying on overt political acts of speech to create public acceptance of extraordinary actions [26]. Thus, as Angela Oels suggests, one might more clearly understand the development of discourses of security around a resource by drawing on the Foucauldian notion of a security dispositif, which emphasizes that "elements as heterogeneous as architectures, discourses, legal texts, institutions, technological devices, and the daily practices of actors are linked by a complex web of relationships and taken together, render a social problem governable as a security issue" [26]. In this case, the social problem to be rendered governable through securitization is the Jordanian population's overuse of the country's water resources. The government has structured its response in the form of a security dispositif by implementing water conservation awareness programs, exactly because these programs can address such a wide range of heterogeneous types of water usage. The documents distributed through this water conservation awareness program touch on a vast variety of topics and contexts within the Jordanian water sector in order to link the two discourses of state insecurity and citizen water use, and through them legitimate the Jordanian state's management of water through the encompassing framework of textual domination detailed above.

This collection of water-related descriptive and prescriptive awareness documents represents a complex discursive formulation that the MWI has repeatedly expanded and rearticulated within the past two decades. Its purpose is to shape the Jordanian population's water use habits and views on national security into a coherent hydraulic social order firmly intertwined with the Jordanian polity, 
which legitimates the state's control of water resources. Despite the vastness of this undertaking, as Messick notes, "textual domination is a partial phenomenon...that intersects in each historical instance with other dimensions of authority" [22]. In analyzing these texts, therefore, this article asserts that the MWI's project of textual domination is ongoing and must be examined in the broader political context of the time. Furthermore, the power of water conservation outreach rests not simply on abstract discursive exchange between state actors and citizens, but invokes tangible forms of Jordanian political authority, such as water laws and water utility costs, which continuously shape the lives of citizens, in order to convince them to accept the security discourse of the impact of water mismanagement on public water supplies.

\subsection{Coercing Participation through Legal and Financial Regimes}

Invoking public concerns over water cost is an effective method of securitizing water usage because fluctuating cost is a constant part of the daily life in Jordan. Since people of average financial means often view water conservation as a luxury, they often also disregard it as a viable daily strategy [27]. Buying supplementary water from the green tanker trucks, which constantly wind their way through Jordan's cities, or the fixed tanks that dot the countryside, can cost up to five Jordanian dinar (JD) per cubic meter, four to five times the cost of normal water service [3]. The cost of these emergency water supplies is so prohibitively high for the average family that "even kids in this country ... they know that they need to be careful because they don't want to run out of water in the last two days of the week and have to rely on bottles or gallons that we bring from other neighborhoods" [3]. This is a problem for middle- and low-income families, rooted in the challenges of an aging infrastructure, particularly in smaller rural communities where the rooftop storage tanks-a sight almost ubiquitous across Jordan-often develop gaps and leakages $[28,29]$. As emerged in the interviews with governmental officials and with NGOs practitioners, despite the ways in which this failure to provide effective water service provides a legitimate context for citizens in rural communities to press claims on the state, both state and non-governmental actors often charge rural communities with wasteful water habits and a failure to uphold their citizen responsibilities, casting them as the culpable parties in both the state insecurity and citizens insecurity discourses.

Through the water payment system, Jordan's government directly and regularly calls on its citizens to do their fiscal part to support the nation's sustainable water resource development. The Yarmouk Water Company, the water authority of Jordan-owned water utility for the northern governorates, has made one such appeal by distributing a pamphlet on the risks of failing to pay regular water costs. It links the timeliness of one's payment directly to the capacity of the Yarmouk Water Company to complete new water projects [30]. In addition, the pamphlet uses the familiar appeal to prudent water usage, fee avoidance, and national pride, claiming, "your initiative in paying the costs of water is a national interest contributing to operational costs" [30], mirroring MWI appeals for water users to see water conservation as "a noble national cause and a national responsibility of all citizens" [20]. This imperative for expedient payments depends not just on appeals to national pride and government support, however, but leverages the intertwining of both legal and infrastructural forms of authority and daily need. This appeal leverages the citizen insecurity discourse-i.e., that of the impact of the personal responsibility of hydraulic citizens on the nation's water supply-in order to mitigate the risk that instability over water shortages could cause to the broader infrastructure. As a part of the MWI's water awareness program, pamphlets like this one contribute to the state's attempts to accomplish a form of textual domination by imbuing daily practices and responsibilities with a larger sense of citizen responsibility through the distribution of texts.

This connection between legitimating state authority and supporting daily needs is clearest in the pamphlet's warning water users to keep paying their bills or risk losing access to water and paying additional fees to restore service [30]. Such a statement effectively grounds abstract government appeals to treat the safety and continuity of the government's water infrastructure with the same consideration as one's own water supply. It frames the consequences of failing the responsibilities of 
hydraulic citizenship in a much more tangible reality, however, emphasizing that if a citizen does not pay and does not contribute with their part, they will not receive any water. One might be tempted to see such a warning in unsurprising, quotidian terms. However, it is important to recognize that the utilization of water costs and penalties are tied up in a broader set of discourses about the relationships between water use, state security, citizen security, and stringent legal frameworks as well. This is especially true when the Jordanian government uses them as a form of authority to codify the state's role as the central entity, owner, and leader of the water sector. The legal inspiration and basis of these water awareness materials lies in a series of laws and by-laws, which codified the MWI's legal authority over the management and development of the state's water resources, and the structure of its two key implementing bodies: the Water Authority of Jordan (WAJ) and the Jordan Valley Authority (JVA) [10]. These by-laws work to collectively establish an institutional framework for the Jordanian government's authority over the development and maintenance of water infrastructure and resources, including provisions on pumping and other extractive practices. Additionally, while the Jordanian government's national water strategy for 2016-2030 highlights the need to develop comprehensive water legislation to recognize the human rights to water and sanitation, the legal framework, as it stands, makes citizens' rights to water access and delivery dependent on the Jordanian government's total and effective authority and management over the nation's water resources [10].

The intersection between legal forms of authority and cost-based motivations in the Jordanian water sector becomes clearer when considering the legal penalties of water infractions. Like the Yarmouk pamphlet, these appeals place a high premium on expediency of cooperation with water standards, impressing upon violators the need to "rush to remove water violations immediately in avoidance of the punishments mentioned in [corresponding] laws [...] in the knowledge that the elimination of the violation will be at the expense of the perpetrator" [31]. Government authorities use ideas of personal cost and legal fines to maintain both consistent citizen support for the expansion of government-operated water infrastructure and continued revenue for the upkeep of the nation's infrastructure. These efforts also work hand in hand with MWI's aims of enforcing water legislation and preventing damage to the infrastructure, to protect the country's water supply and the technological apparatus that renders it available to water users. The MWI has in fact stated that it intentionally frames water conservation awareness in terms of legal transgressions and punishments to make each citizen aware of the negative impacts of poor water use habits and neglect of national infrastructure [32]. Water conservation materials that employ legal authority to shape citizens' treatment of water resources deal mostly with mitigating two particular problems: misuse or damage of state-owned water infrastructure and wasteful water habits. In this way, they directly tie together the citizen insecurity and state insecurity discourses with which the Jordanian state securitizes water usage. While the later series of suggestions on correcting wasteful water habits leverages the citizen insecurity discourse to convince people that it is to their own security and benefit to conserve water, the prior prohibitions against misusing or damaging the state-owned water infrastructure is directly indebted to the state insecurity discourse, casting potential citizen behaviors as a threat to Jordan's broader water and national security. Codifying these two discourses in the same series of legal regulations and financial penalties allows the state to link the discourses of citizen and state insecurity, defining them as part of the same broader continuum of water insecure behaviors. In this way, the state aims to extend its control over citizens' water usage, casting their failures to use water in a manner the state labels as responsible as a failure to abide by the rules of the hydraulic citizen-state relationship.

Consequently, it is succeeding or failing to consistently pay one's water bills that establishes the importance of proper, full, and legal participation in the material exchanges of the nation's water infrastructure, a key part of the fulfilling one's hydraulic citizenship responsibilities. This act is at the core of the relationship between the mandates of state water providers and the ascribed responsibilities of citizen water users. Such participation makes possible the maintenance of state-owned property, and so it is not surprising that according to the Yarmouk Water Company, one of the punishments for failing to uphold this arrangement is private property seizure [30]. 
This is a form of coercively linking "water awareness" and support for national infrastructure, which the MWI also uses in cell phone text messages it sends to water users, labeled "Conserving Water: Practical Methods." The MWI disseminates these texts by passing them to the most popular cell service carriers in the country, who then send them to their users. This collection of texts leverages both the citizen and state insecurity discourses, teaching personal water efficiency and issuing prescriptive warnings as well. While many of these messages include advice about effective daily water use, the final set of texts proclaims the legal punishments for violating sites of state control over water and infractions upon the security of its water infrastructure:

"Each one of [these] shall be punished by imprisonment for a period that is no less than a year and does not exceed five years and a fine no less than 2000 Dinar and that does not exceed 7000 Dinar:

- Attacking the mobile water lines (water tankers) and the main water lines.

- Digging groundwater wells without a license.

- Attacking sewage plants, pumping stations, and "water desalination technology".

- Causing/creating pollution in well-water collection/harvesting reservoirs, water tankers and water mains" [31].

The MWI combines these punishments with the securitizing discourse of state insecurity to focus on transgressions against state-controlled water infrastructure, suggesting that their concern with risks to infrastructure security is high. While security risks to sites of water infrastructure most directly impact the communities that rely directly on them, the focus of these texts also suggests that the state is explicitly concerned with attacks against its sovereign property, and especially the drilling of wells [33], and thus situates these transgressions within the state insecurity discourse. Furthermore, these texts and the legal and financial penalties they cite represent the MWI's attempt to interlock water usage and all its related social and practical activities with Jordan's larger political order. The wide range of activities represented in these texts emulates Foucault's security dispositif and the ways in which codifying the diverse linkages between the water practices in these texts and penalizing them renders the social problem of water usage governable. In rendering water usage governable in this manner, such texts rely upon the interlocked discourses of citizen and state insecurity to cultivate popular acceptance to these policies. It is in the event of the failure of these documents to promote behavioral change and respect of state policies that the state invokes punitive measures.

These messages are not just theoretical. They reinforce a program of surveillance and protection the state has extended over access points to the nation's water infrastructure. This came as a response to domestic incidents where the state has seen tensions over ineffective water infrastructure develop into "attacks, tampering, or security breach[es]" [33]. This increased surveillance program has since evolved into a full-fledged Water Resource Security Plan aimed at mitigating risks to the nation's water infrastructure, ranging from vandalism and misuse to potential terror attacks [10]. As a result, ascribing legal and security consequences to water infractions demonstrates the heavy responsibility for all "custodians of water" in Jordan, explicitly linking their water security with national security [10]. This kind of rhetoric places the responsibility for the custodianship of water on citizens, linking their security with that of the state's water infrastructure through a coercive legal framework. Furthermore, this system connects state and citizen in a way that precludes forms of dissent or protest, insisting that one cannot be at risk without the other being in danger as well.

The forms of infrastructure damage that the above documents describe not only threaten the security of state water resources and state-owned spaces in a broader sense, but also present problems to the state by creating gaps in the infrastructure through which water is lost. While the gaps that the above legal measures work against are material in nature, non-revenue water (NRW) constitutes another "gap" in state control of the water system. In the broadest sense, the definition of NRW encompasses any form of water usage that is "non-legislated, i.e., any consumption of water without paying the price of the consumed water, whether by tampering with the meter or the presence of an illegal connection" [34]. Like the infractions mentioned above, the MWI uses water awareness programs 
to convince people not to steal from the state [34], calling on discourse linking personal water use to the security of public water supplies to do so. As of 2012, NRW was over 50\% in much of the country [35]. It was even higher in particular parts of the country, such as Mafraq in 2013, where "physical and administrative losses" accounted for $61 \%$ of total resources supplied by the water network [36]. While physical losses refer to water lost through Jordan's aging extraction and distribution infrastructure, it is administrative losses, which would be more properly termed political losses, which are the target of most legislative and punitive legal efforts. An environmental non-governmental organization (NGO) director whom I interviewed framed the problem of NRW as follows:

People who steal little, or too much are [in] the same book, so we need to go after each one of them to be able to control our water resources in general [ ... ]. We need to implement the law and unfortunately influential people tap on the resources of water without paying anything. You drive through the desert and you see this huge big farm with sky high tall trees and greenery and maybe even fish farms and so you wonder, do they pay for the water? No they don't. The resources in the country belong to the country itself. That means that all those private wells must go back to the control of the government. You need laws and regulations and the police force to be with them all the time and like we said it's influential people, that means a water inspector will not be able to just open the gate of a farm and walk in, he might be shot for that [29].

The director pointed to some of the key aspects of addressing issues of NRW, legislation, and the legitimacy of government authority in Jordan. First, the coercive frameworks of state water authority do not map out onto all sections of the population evenly. The NGO director couched this claim in terms of a political taboo: the political influence of many of the larger farm owners in Jordan-this includes present or past parliamentarians, ministers, or even members of the Royal Court-makes water consumption reforms difficult [37]. This leads to diverging logics of water use between the state and private landowners, in which landowners conceive of the Kingdom's water resources as sources of personal wealth. This logic directly contradicts the legitimacy state water ownership, which pervades all of the previous texts and is one of the main reasons that the Jordanian government has continued to support securitizing water awareness programs. It is this notion of unconditional state ownership of water resources MWI seeks to convince citizens of through its outreach programs. The core of this political project is to convince people that the state's control of Jordan's water resources must be respected if the country's resources are to remain secure for the future. MWI has devoted much time to implementing this message through civil society engagement and awareness programs, which link the security of state water resources with the security of personal water supplies. One of the most prominent MWI programs of engagement with civil society depended on the legitimizing of state authority over water, specifically using the influence of religion and religious texts.

\subsection{Water, Religion, and Respect for the State}

An essential component of the construction of the MWI's authority over the nation's water resources lies in forging links between water conservation awareness, the religious meanings of water, and the state's ownership of water resources. The focus on this connection between Islam and water truly began with the Water Efficiency and Public Information for Action program (WEPIA), in 2001. This USAID-funded program-which worked with the Ministry of Awqaf and Islamic Affairs, the Ministry of Water and Irrigation, and the Jordan Environment Society-formally trained approximately 1000 Muslim and Christian religious leaders about the urgent need to conserve water, so that they would in turn disseminate this information in their respective communities [38]. Because the majority of Jordanians identify as Muslims, the training focused on establishing new norms for water usage within mosques [39]. An MWI official whom I interviewed described the efforts of the MWI in merging water conservation awareness with religious concerns as follows:

We produce [for the mosques] materials as a reference and have asked the awqaf minister to encourage Imams to do a khutba every Friday, talking about water. We have also talked with Islamic [scholars] in order to take a fatwa for some kinds of behavior that are not [water efficient]. We have 
collected all the ayaats, ahaam, and all the Prophet Muhammad's sayings and his behavior which talk about water conservation ... and distributed these to all Jordanians [40].

The point of these efforts was to evoke religious authority in several ways to legitimize state authority over water. First, the program used religious texts, such as the fatwas and the citation of suras [41], as well as publications on water and its use in religious spaces sent out to schools and other civil society entities, to situate water conservation behaviors within a context of religious requirements and stipulations as well as government ones. In addition, this program influenced the public's perception of the importance of state water conservation programs by channeling these messages through individuals with positions of religious authority and community leadership (i.e., Imams and waethat, female lay-preachers) [39]. The intent of this program was to link the state's legitimacy of water authority with the authority of citizens' religious communities to strengthen appeals of personal water responsibility and hydraulic citizenship by entangling them with appeals to leading a pious life within Jordan's religious communities. In addition to programming directed at the general public, WEPIA also specifically targeted women, who the implementing partners viewed as essential targets for education as they are often responsible for controlling a large portion of domestic water usage. In evidence to the very explicit intentions behind this program, WEPIA's 2005 final report states "WEPIA planned to follow up with the Imams and use their influence in neighborhoods to assist with collecting water audit forms from homes around mosques." Taken together, these efforts provide a picture of the desires of the Jordanian government and its partners to involve religious civil society entities in orienting individual water habits towards reflecting the state's two securitizing discourses, and so work daily to preserve the nation and the government, as well as bringing them into the apparatus of information collection.

The MWI strives to develop its own sense of authority by situating itself within a preexisting landscape of religious texts. One MWI pamphlet entitled "Saving Water in Islam" clearly places the Jordanian state within a religious framework:

Waters are considered publicly owned and are managed by the state; there may not be a monopoly of waters by any person, and this is what the prophet confirmed (prayers and peace be upon him) in an address to his friend, may God be pleased with him. God's prophet (prayers and peace be upon him) said "the bringer is blessed and the monopolist is cursed" as he said (prayers and peace be upon him) "no one hoards except in error" [39].

By employing a hadith, this pamphlet seeks to establish the state as the primary manager of the Kingdom's water resources, giving it the authority—seemingly not just political but religiously based as well-to regulate the use of water as it sees fit, and encouraging the Jordanian population not to attempt to coopt these waters for their own usage. This work with the religious leadership of Jordan shows the attempt of the MWI to reach civil society entities within government leadership, as documented in ministry outreach materials. However, this program also displayed some of the challenging aspects of internationally funded state-civil society engagement; sustainability and continuity. The most problematic aspect of this program was that "once the funding stopped, it faded away in a way, you know its religious people stopped talking about it" [42]. This observation was corroborated by the WEPIA program final report, which mentioned limited funding and lack of financial incentives for Imams, as well as gaps in communication between WEPIA and the Jordan Environment Society (JES) regarding the goals of the project as issues that undercut the sustainability of the program [6]. Despite the strong leadership that the MWI may have had in this program then, limited international funding and the inclusion of implementing civil society organizations served to circumscribe the Ministry's ability to directly shape the water habits of the population. The MWI's application of state authority through civil society organizations was not a straightforward process of bureaucratic power, but just one variable among many in determining outcomes. The security implications of this fact are that the Jordanian government does not yet possess sufficiently total control over the development of civil society water awareness programs for them to sufficiently act as a consistent medium for mitigating its perceived security concerns at the local level. Therefore, the Jordanian government's capacity to 
securitize water usage through water awareness programs, and thus its capacity to increase its control over its citizens daily water practices is circumscribed by the relative sparsity of civil society resources and their dependence on international funding. The MWI's efforts have met with a different series of successes and challenges in the implementation of a water conservation curriculum.

\subsection{The Jordanian Education System and the Role of the Water Conservation Curriculum}

The MWI, in collaboration with the Ministry of Education, disseminated information on water scarcity in Jordan through textbooks in order to raise awareness about water challenges and shape students' behavior [17]. In order to understand how the educational system serves as a platform for propagating knowledge related to the water situation in Jordan, its causes, and possible solutions, we surveyed science and geography textbooks used from the first to tenth grades in Jordan. Analysis revealed considerable emphasis on the acuteness of the water shortage in Jordan, with the sentence "Jordan is the fourth water-scarce country in the world" being almost omnipresent. These textbooks also suggested that a major remedy to the problem is two-folded: support for mega water development projects-such as the Disi and the Red Sea and Dead Sea projects, and a change in students' and the population's water behaviors. In the textbooks' formulation, the latter can be achieved by reducing water consumption at home (e.g., when washing cars, gardening, and showering), as well as in the agricultural sector. Moreover, the community benefits—rather than the individual benefits-are emphasized in order to convince the students that it is a national priority, it is for the good of the country, and that the new water friendly behavior needs to be adopted [17]. In linking these two types of solutions to water scarcity and insecurity, these education materials utilize both types of security discourses to both convince students of the efficacy and importance of mega-projects and larger state infrastructure networks and enjoin them to do their part to alleviate water stress as way of learning the responsibilities of hydraulic citizenship.

\section{Conclusions}

This article made three original contributions to knowledge. The first is identifying the two interlocking discourses of citizen insecurity and state insecurity as central to the Jordanian state's project of securitizing water. The second is analyzing Jordan's water conservation awareness program documents as a form of evidence to the state's sense of national insecurity around citizens' water habits, and as a method of alleviating that insecurity. The third is applying textual analytical and interview methods to understand how state actors, nonstate actors, and citizens conceptualize their mutual roles and responsibilities over providing and using water resources, and how failures to meet these responsibilities on either end create water insecurity.

The first contribution is about highlighting the fact that the key to the Jordanian government's strategy of change in water conservation behavior is a multi-polar and multi-methodological approach, intertwining the two water security discourses that this article has examined. We have labeled the first discourse "state insecurity" and the second "citizen insecurity." Most of the MWI's water conservation awareness materials very explicitly adopt the discourse of citizen insecurity through wasteful personal water use habits, and profess methods of mitigating this waste. However, our analysis of water conservation awareness documents and interviews with state and non-state water sector professionals demonstrates that Jordan's national water strategy and complex definition of the risks of water scarcity attributes to citizens and their water behavior a pivotal role in the state's stability and security. Using a combination of prescriptive rhetoric and legal frameworks, the Ministry of Water and Irrigation convinces and compels the population to shift its habits based upon assimilating ideas of hydraulic citizenship as a form of belonging and responsibility to the national water network. The aim of joining the two discourses of state and citizen insecurity through this relationship of hydraulic citizenship is convincing the members of Jordan's society that their daily water practices have a powerful impact on the nation's security. This is combined with explicit legal and financial restrictions on how one should 
use water and what happens if one fails to do so, in order to show citizens that failure to embrace productive, responsible hydraulic citizenship results in a variety of punitive measures.

The second contribution is analyzing Jordan's water conservation awareness program as a method of mitigating state insecurity and extending state control through textual domination. At the level of practical engagement, the MWI performs outreach to the population through circulation of a diverse series of materials distributed through water utilities, religious institutions, civil society organizations, and schools with the purpose of fully securitizing Jordan's water resources and their use. We have argued that these processes or production, distribution, and raising awareness constitute processes of textual domination and securitization reminiscent of the Foucauldian security concept of a security dispositif. The Jordanian government devotes extensive resources to this project, precisely because it sees both citizens' respect for physical infrastructure and water use habits as potential existential security threats to the nation itself. It thus produces a variety of awareness texts utilizing the two discourses we have labeled as a way to make obedience to state water policies part of the social order of daily life, and to render citizens' water use governable and punishable.

The third contribution is about drawing from these first two contributions to understand the state-citizen relationship over water usage and conservation and the implications of either side's failures to fulfil the responsibilities of that relationship. Throughout the interviews we conducted and texts we analyzed, we found a range of levels of support and criticism for Jordan's water conservation programs. Despite these water awareness campaigns' efforts to incorporate all aspects of social and daily water use into the Jordanian polity, the success of these methods of coercing behavioral change remains uncertain, as the Jordanian population still has not fully adopted the conservation measures outlined in the government's water conservation awareness materials. The result of this is that the Jordanian government may well resort to more direct forms of securitization and harsher and more authoritarian measures as Jordan's water scarcity crisis worsens, creating far stricter requirements for the state-public hydraulic citizenship relationship. The national water strategy of 2016-2030 specifically points to this, announcing new security measures to further monitor water infrastructure access points, and to integrate the water infrastructure into the domain of Jordanian security organizations [35]. This shift also has implications for the restriction of citizens' possible everyday access to various water infrastructure points throughout the kingdom and the increasing intensity of the project of state securitization of water resources, creating additional difficulties and insecurities for citizens' daily water supply and usage. Overall, this analysis and the two interwoven security discourses at its core indicated that the Jordanian government's concern over citizens' water use habits is driving the state to devote more resources towards behavior change as a method of water demand management. Not only does this address citizen water usage as a source of insecurity, but it also provides a plausible alternative to more extreme securitizing measures, such as supply reduction, which could provoke further public outcries and a subsequent breakdown in the state-population hydraulic citizenship relationship that Jordan's water laws have attempted to codify.

Author Contributions: Both authors contributed to the research design, analysis, and drafting of the manuscript. Funding: This research received no external funding.

Acknowledgments: The first author would like to thank to all of his writing peers and colleagues who reviewed and provided feedback on this research throughout its development. In addition, this research benefited greatly from the excellent support, feedback, and ethnographic mentorship of Rochelle Davis and Fida Adely. Finally, this research would not have been possible without the insights, support, and excellent academic mentorship of Marwa Daoudy. To these individuals and to all those who gave their time and efforts to participate in this research, I say thank you.

Conflicts of Interest: The authors declare no conflict of interest.

\section{References and Notes}

1. Anonymous. Interview 1: National Perspectives on Water Awareness Campaigns. p. 4. Amman, Jordan, 2016.

2. Anonymous. Interview 2: Water Awareness Campaigns and International NGOs. p. 4. Amman, Jordan, 2016. 
3. Anonymous. Interview 6: Water Awareness Campaigns in Northern Jordan. pp. 3-4. Amman, Jordan, 2016.

4. Haddadin, H.J.; Shteiwi, M. Linkages with Social and Cultural Issues. In Water Resources in Jordan: Evolving Policies for Development, the Environment, and Conflict Resolution; Munther, J.H., Ed.; Resources for the Future: Washington, DC, USA, 2006; p. 215.

5. Elmusa, S. A Harvest of Technology; Georgetown University Center for Contemporary Arab Studies: Washington, DC, USA, 1994; p. 32.

6. United States Agency for International Development (USAID). Water Efficiency and Public Information for Action (WEPIA) Program, 2000-2005 Final Report; Academy for Educational Development and US Agency for International Development: Durham, UK, 2005.

7. Ministry of Water and Irrigation (MWI). Jordan's Water Strategies and Policies; Ministry of Water and Irrigation: Amman, Jordan, 2004; p. 24.

8. Weinthal, E.; Zawahri, N.; Sowers, J. Securitizing Water, Climate, and Migration in Israel, Jordan, and Syria; Springer Science + Business Media: Berlin, Germany, 2015; pp. 293-307.

9. Toppo, D. Political Agitation and Water Shortages in the Hashemite Kingdom of Jordan; Claremont McKenna College: Claremont, CA, USA, 2015; p. 9.

10. Ministry of Water and Irrigation (MWI). Ministry of Water and Irrigation National Water Strategy 2016-2030; Ministry of Water and Irrigation: Amman, Jordan, 2015; pp. 4, 5, 8, 17, 18, 24.

11. Zietlow, K.J.; Michalscheck, M. Water Conservation Behaviour under Scarcity Conditions-Exploring the Impact of Socio-demographic and Housing Determinants in Jordan. In Social Water Studies in the Arab Region: State of the Art and Perspectives; German Jordan University: Madaba, Jordan, 2015; pp. 132, 137.

12. United Nations (UN). Jordan pins water hopes on controversial pipeline project. In Refugees Daily (Amman, Jordan); UN Integrated Regional Information Networks: New York, NY, USA, 2014.

13. March, H.; Domènech, L.; Saurí, D. Water conservation campaigns and citizen perceptions: The drought of 2007-2008 in the Metropolitan Area of Barcelona. Nat. Hazards 2013, 65, 1951-1966. [CrossRef]

14. March, H.; Hernández Hernández, M.; Sauri, D. Assessing Domestic Water Use Habits for More Effective Water Awareness Campaigns During Drought Periods: A Case Study in alicante, Eastern Spain. Nat. Hazards Earth Syst. Sci. 2015, 15, 963-972. [CrossRef]

15. Magiera, P.; Taha, S.; Nolte, L. Water demand management in the Middle East and North Africa. Manag. Environ. Qual. Int. J. 2006, 17, 289-298. [CrossRef]

16. Atallah, S.; Khan, M.A.; Malkawi, M. Water conservation through public awareness based on Islamic teachings in the Eastern Mediterranean region. In Water Management in Islam; United Nations University Press: Tokyo, Japan, 2001; pp. 49-60.

17. Hussein, H. A critique of water scarcity discourses in educational policy and textbooks in Jordan. J. Environ. Educ. 2018, 49, 260-271. [CrossRef]

18. Zietlow, K.J.; Michalscheck, M.; Weltin, M. Water conservation under scarcity conditions: Testing the long-run effectiveness of a water conservation awareness campaign in Jordan. Int. J. Water Resour. Dev. 2016, 32, 997-1009. [CrossRef]

19. Anand, N. Pressure: The PoliTechnics of Water Supply in Mumbai. Cult. Anthropol. 2011, 26, 544. [CrossRef]

20. Ministry of Water and Irrigation (MWI). Residential Water Use and Efficiency Guide; USAID/Jordan: Amman, Jordan, 2011; pp. 4, 8.

21. Anand, N. Hydraulic City: Water $\mathcal{E}$ The Infrastructures of Citizenship in Mumbai; Duke University Press: Durham, NC, USA, 2017; pp. 9-10.

22. Messick, B. The Calligraphic State: Textual Domination and History in a Muslim Society; University of California Press: Berkeley, CA, USA, 1993; p. 1.

23. Anonymous. Interview 3: Enacting Water Resource Management within Daily Water Use Routines. p. 5. Amman, Jordan, 2016.

24. Ministry of Water and Irrigation (MWI). Jüdat Miyāh al-Shurb F̄̄ al-Urdun (The Quality of Drinking Water in Jordan); Ministry of Water and Irrigation: Amman, Jordan, 2007; p. 4.

25. Anonymous. Interview 4: Urban Water Access and Citizenship. p. 3. Amman, Jordan, 2016.

26. Oels, A. From 'Securitization' of Climate Change to 'Climatization' of the Security Field: Comparing Three Theoretical Perspectives. In Climate Change, Human Security and Violent Conflict; Scheffran, J., Brzoska, M., Brauch, H.G., Link, P.M., Schilling, J., Eds.; Springer: Berlin/Heidelberg, Germany, 2012; pp. 191-198.

27. Anonymous. Interview 5. NGO Perspectives on Water Conservation as a Luxury. p. 4. Amman, Jordan, 2016. 
28. Anonymous. Interview 7: Water Awareness Campaigns and Local NGOs. p.1. Amman, Jordan, 2016.

29. Anonymous. Interview 8: Water Awareness Campaigns, Local NGOs, and Water Costs. pp. 1-2. Amman, Jordan, 2016.

30. YWC; Directorate of Media; Water Awareness. Bādir ilā Dafa' Athmān al-Miyāh wa la Turākim al-Fawātīr (Take the Initiative to Pay Water Costs and Don't Accrue Fees); Yarmouk Water Company: Irbid, Jordan, 2013; p. 1.

31. Ministry of Water and Irrigation (MWI); Information \& Communication Technology Unit. al-Hifäz 'alā al-Miyāh: Turuq 'amaliyyah (Conserving Water: Practical Methods); Ministry of Water and Irrigation: Amman, Jordan, 2016.

32. Ministry of Water and Irrigation (MWI); Water Demand Management: Introduction. Ministry of Water and Irrigation of the Hashemite Kingdom of Jordan; Ministry of Water and Irrigation: Amman, Jordan, 2017.

33. Ministry of Water and Irrigation (MWI). MWI Annual Report 2015; Ministry of Water and Irrigation: Amman, Jordan, 2015; pp. 26, 39.

34. Ministry of Water and Irrigation (MWI). Tarshīd Istihlāk al-Miyāh (Rationalizing Water Consumption); Ministry of Water and Irrigation: Amman, Jordan, 2001; p. 12.

35. Ministry of Water and Irrigation (MWI). Water for Life: Jordan's Water Strategy 2008-2022; Ministry of Water and Irrigation: Amman, Jordan, 2009; pp. 24, 30.

36. Ministry of Water and Irrigation (MWI); MOPIC. High Level Conference on Jordan's Water Crisis; Ministry of Water and Irrigation: Amman, Jordan, 2013; p. 21.

37. Anonymous. Interview 9. NGO Perspectives on State Water Conservation Policies and Conflicts of Interest within the Water Sector. pp. 4-5. Amman, Jordan, 2016.

38. Charkasi, D. Water Conservation Programme Relies on Message of Religious Texts; The Jordan Times: Amman, Jordan, 2001; p. 16.

39. Ministry of Water and Irrigation (MWI); Ministry of Religious Endowments; Sacred Islamic Matters, German Cooperation. Tawfìr al-Mā' fì al-Islām (Conserving Water in Islam); Ministry of Water and Irrigation: Amman, Jordan, 2015; p. 4.

40. Anonymous. Interview 10: The Ministry Perspective on Water Awareness Campaigns. p. 8. Amman, Jordan, 2016.

41. Ministry of Water and Irrigation (MWI); Directorate of Media; Water Awareness and the National Campaign for Water Awareness. Miyāh al-Sarf al-Sahī fĩ al-Urdun (Wastewater in Jordan); Ministry of Water and Irrigation: Amman, Jordan, 2005; p. 12.

42. Anonymous. Interview 11: The Challenges of State-Civil Society Engagement. p. 7. Amman, Jordan, 2016. 